\title{
PENGORGANISASIAN DOKUMEN DALAM KEGIATAN KEPUSTAKAWANAN
}

\author{
Agung Nugrohoadhi*
}

Pengutipan: Nugrohoadhi, A. (2015). Pengorganisasian dokumen dalam kegiatan kepustakawanan. Jurnal Ilmu Perpustakaan, Informasi, dan Kearsipan Khizanah Al-Hikmah, 3(1), 1-10. Diambil dari http://journal.uin-alauddin.ac.id/index.php/khizanah-al-hikmah/article/view/584

\section{*Pustakawan Universitas Atma Jaya Yokyakarta agungnugrohoadhi@gmail.com}

\begin{abstract}
ABSTRAK
Dokumentasi dan arsip merupakan dua istilah yang biasanya digunakan bersama-sama. Dokumentasi memiliki arti yang lebih luas daripada arsip. Fungsi manajemen arsip yang baik diperlukan sehingga proses pekerjaan dapat berlangsung dengan baik. Manajemen sebagai proses untuk mencapai tujuan organisasi memerlukan dokumentasi yang dapat memberikan bantuannya bila diperlukan. Salah satu fungsi dokumen adalah sebagai sarana pengingat yang disimpan dalam berbagai bentuk, dan dengan demikian maka diperlukan sistem temu kembali yang efisien dan efektif. Pengorganisasian dokumen di Perpustakaan Universitas Atma Jaya Yogyakarta telah menerapkan sistem temu kembali yang bermanfaat bagi para pustakawan dan pengelola perpustakaan serta para pemustaka. Kegiatan pengorganisasian dokumen meliputi inventarisasi, pengkatalogan, susunan dokumen, dan temu kembali dokumen.
\end{abstract}

Kata Kunci : organisasi informasi, sistem temu kembali

\section{ABSTRACT}

Documentation and archive are two different terms that interchangeably used by people. Documentation has wider scope than archive. A robust archive management is needed in order to get the work well. Management, as a process to achieve organization goals, needs documentations when needed. One of the usefull of documentation is as a bibliographic tool in which it needs an information retrieval system to organize efisiently and effectively. Organization information activity in Universitas Atma Jaya Library has been using an information retrieval system in order to benefit the librarians and the users as well. The activity includes inventory, cataloging, document order, and document retrieval tool.

Key Words: organization information, retrieval system

\section{PENDAHULUAN}

\section{a. Dokumentasi dan Kearsipan}

Kegiatan dokumentasi dan arsip sering dipergunakan secara bersama-sama dan menimbulkan kebingungan, arsip sering disebut dokumen sedangkan kearsipan sering disebut dokumentasi. Dua istilah ini sering dipergunakan secara bersama-sama tanpa memberikan perbedaan yang jelas. Dokumentasi dibedakan menjadi dua pengertian yang berbeda. Pemisahan ini 
didasarkan pada jenis koleksi dokumennya itu sendiri yaitu:

1) Dokumentasi korporil, artinya penyimpanan dan temu kembali benda bukan pustaka, seperti : foto, preparat dan benda-benda antik.

2) Dokumentasi literer, artinya dokumentasi pustaka

Sedangkan menurut kamus Administrasi Perkantoran yang dikutip oleh Wursanto dokumen adalah warkat asli yang dipergunakan sebagai alat pembuktian atau sebagai bahan untuk mendukung suatu keterangan. Dijelaskan lebih lanjut bahwa istilah document dalam dunia pengusaha di luar negeri, misalnya di Amerika Serikat, diartikan sama dengan record atau warkat. Dalam perkembangan selanjutnya, istilah document berarti naskah-naskah asli yang telah didaftar secara sah menurut ketentuanketentuan dalam suatu peraturan (piagam atau traktat) (Wursanto, 1991). Soejono Trimo mengatakan bahwa yang dimaksud dengan dokumen adalah semua bahan pustaka, baik dalam bentuk tulisan, cetakan maupun dalam bentuk rekaman lainnya seperti pita suara/cassette, video, tapes, film, filmstrip, slide, mikrofilm, mikrofis, gambar dan foto (Soejono Trimo, 1987).

Arsip menurut Undang-undang Nomor 43 tahun 2009 tentang Kearsipan adalah rekaman kegiatan atau peristiwa dalam berbagai bentuk media sesuai dengan perkembangan teknologi informasi dan komunikasi yang dibuat dan diterima oleh lembaga negara, pemerintah daerah, lembaga pendidikan, perusahaan, organisasi politik, organisasi kemasyarakatan dan perseorangan dalam pelaksanaan kehidupan bermasyarakat, berbangsa dan bernegara (Anna Nunuk, 2011).

Dokumentasi memiliki kegiatan yang lebih luas daripada arsip. Menurut Federation International d'Information et de Documentation (FID) dokumentasi ialah penyusunan, penyimpanan, temu balik, penyebaran dan evaluasi informasi, bagaimanapun cara merekamnya dalam bidang sains, teknologi, seni dan kemanusiaan. Dokumentasi lebih luas daripada arsip karena dalam dokumentasi termasuk pula berbagai materi yang dicakup di perpustakaan (seperti buku dan majalah), dokumentasi juga bertugas membuat dokumen baru dari dokumen yang ada (berupa bibliografi, majalah indeks dan abstrak) sesuatu yang tidak dilakukan oleh arsip. Secara tradisi kegiatan dokumentasi hanya terbatas pada informasi ilmiah sedangkan jasa yang diberikan lebih banyak untuk ilmuwan sedangkan arsip tidak selalu terbatas pada ilmuwan dan informasi yang diberikannya tidak selalu bersifat ilmiah (Sulistyo Basuki, 2013). Maka dengan sedikit uraian ini akan dapat memperjelas perbedaan antara arsip dan dokumen yang selama ini dianggap sama.

\section{b. Sejarah Dokumentasi}

Menurut Sulistyo Basuki, istilah dokumentasi dikemukakan pertama kali pada tahun 1895, yaitu saat Paul Ottlet menyebutkan istilah dokumentasi. Ketika itu dokumentasi berarti pengawasan bibliografi, yaitu usaha pencatatan setiap buku yang diterbitkan dalam sebuah kartu berukuran 10 $x 12,5, \mathrm{~cm}$. Tujuannya adalah untuk menyusun bibliografi universal. Namun ketika penerbitan majalah ilmiah mulai berkembang pesat, yaitu sekitar abad ke 18 dan 19, maka pencatatan buku beralih ke pekerjaan mencatat setiap terbitan majalah Ilmiah. Pekerjaan tersebut, di Eropa Barat dilakukan oleh orang-orang yang menyebut dirinya dokumentalis, sedangkan di Amerika serikat dilakukan oleh orang-orang yang bekerja di perpustakaan khusus, yang pada perkembangannya lebih lanjut, profesi dokumentalis merupakan cikal bakal profesi spesialis subjek (subject specialist) yang sangat diperlukan di perpustakaan-perpustakaan khusus. Ketika perang dunia II, kegiatan dokumentasi beralih menjadi mengurus bahan pustaka berbentuk mikro, seperti mikrofilm ataupun gulungan film dalam bentuk kecil. Bahan-bahan tersebut beredar untuk keperluan mata-mata. Dengan demikian berdasarkan sejarah tersebut diatas, 
makna profesi dokumentalis telah mengalami beberapa perubahan sesuai dengn situasi dan kondisi yang sedang berlangsung. Dalam hubungannya dengan keberadaan pendokumantasian sebagai salah satu profesi, akhir-akhir ini yang dimaksud dengan dokumentasi adalah pekerjaan yang berkaitan dengan pengumpulan/akuisisi, penanganan dan penyebaran informasi, terutama bahan pustaka yang berupa laporan ilmiah, yang bersifat semi publikasi, statistik dan lain-lain (Sulistyo basuki, 2004).

\section{c. Dokumentasi Dalam Masa Kekinian}

Seperti telah dijelaskan di atas bahwa bidang gerak dokumentasi lebih luas daripada kearsipan maka kearsipan dapat dikatakan merupakan bagian dari dokumentasi yang dapat dibagi menjadi 3 bidang yaitu :

1) Dokumentasi literer atau dokumentasi pustaka

2) Dokumentasi korporil atau dokumentasi benda yang merupakan bahan-bahan bagi dokumentasi benda yang merupakan bahan-bahan bagi dokumentasi museum

3) Dokumentasi privat atau dokumentasi kearsipan

Dengan demikian dokumentasi meliputi tugas kearsipan, perpustakaan dan kemuseuman sehingga dokumentasi sangat penting dalam setiap kegiatan apapun. Bidang dokumentasi antara lain mempunyai tugas berikut :

1) Mengumpulkan bahan-bahan yang mempunyai nilai. Kegiatan mengumpulkan bahan-bahan ini terdiri dari kegiatan mencari dan menyeleksi bahan-bahan /informasi.

2) Mengolah bahan-bahan, data-data/faktafakta tersebut secara sistematis.

3) Menyusun atau menata bahan-bahan, data-data/ fakta-fakta tersebut secara sistematis.

4) Mempersatukan/mengelompokkan bahan-bahan yang sama dan yang berkaitan satu dengan yang lain.
5) Menyiapkan bahan-bahan, data, fakta dokumen tersebut untuk memenuhi kebutuhan bagi pihak yang memerlukan.

6) Menyimpan dan memelihara bahanbahan, data, dokumen secara sistematis.

7) Menyebarluaskan bahan-bahan, data, akta, dokumen secara selektif kepada pemakai jasa atau pihak yang memerlukan, baik yang diminta maupun tidak diminta.

Tentang tugas dan kewajiban pengelolaan dokumentasi sebenarnya telah diatur dalam Peraturan Presiden No. 20 tahun 1961 Tentang Tugas dan Kewajiban dan lapangan Pekerjaan Dokumentasi dan Perpustakaan dalam lingkungan pemerintah (lembaran Negara tahun 1961 No. 311. Tambahan Lembaran Negara 2369. Dalam pasal 2 ayat (1) Peraturan Presiden itu ditetapkan bahwa tugas kewajiban dokumentasi ialah menyediakan keterangan-keterangan dalam bentuk dokumen baru tentang pengetahuan dalam arti kata luas sebagai hasil kegiatan manusia dan untuk keperluan itu mengumpulkan dan menyusun keteranganketerangan tersebut. Ditegaskan lebih lanjut bahwa dokumentasi menjalankan pekerjaanpekerjaan sebagai berikut (pasal 3) :

1) Menyediakan keterangan-keterangan yang dikutip, disadur, diterjemahkan, disaring, difotokopi atau direkam dari segala dokumen pustaka.

2) Memberitahukan perihal tersedianya keterangan-keterangan itu.

3) Atas permintaan menyusun suatu dokumen baru sebagai lanjutan dari usaha dimaksud pada angka/butir (Wursanto, 1991).

Seperti telah dijelaskan di atas bahwa dokumentasi dibagi menjadi 2 macam yaitu dokumentasi literer dan dokumen korporil. Dokumentasi literer lebih berorientasi pada dokumen tekstual sedangkan korporil pada dokumen nontekstual. Dengan kata lain dokumen korporil mengarah kepada museum. Hanya saja museum terbuka untuk umum sementara dokumentasi lebih menekankan pada pengguna yang biasanya 
adalah ilmuwan. Bila digabungkan dengan perpustakaan, museum dan arsip, maka perbedaan antar empat unit tersebut dapat dilihat pada tabel seperti berikut ini:

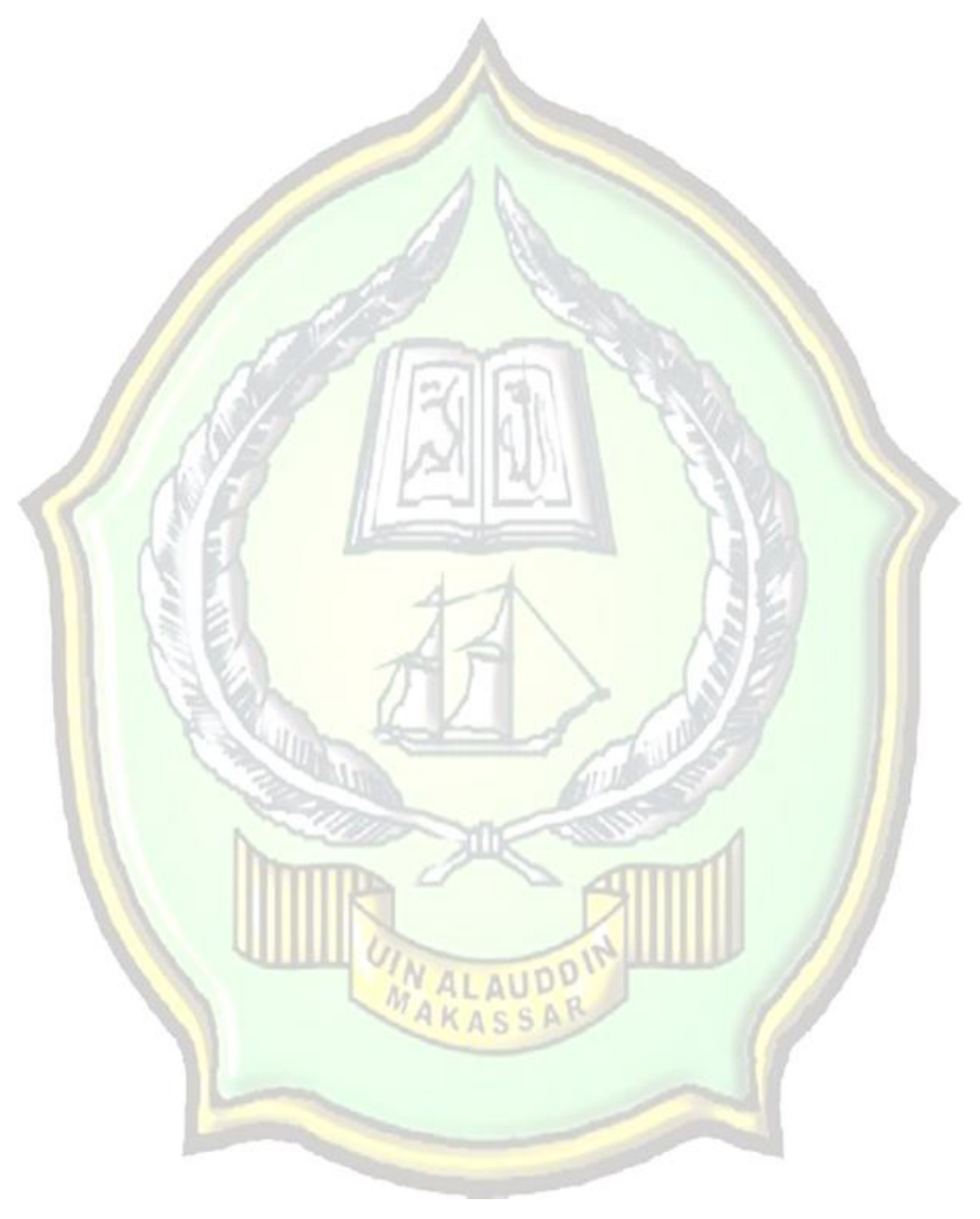




\begin{tabular}{|c|c|c|c|c|c|c|c|c|c|}
\hline Uraian & Pusat Rekord & Depo Arsip & Perpustakaan & Museum & \multirow[t]{2}{*}{ Pemakai } & \multirow[b]{2}{*}{$\begin{array}{l}\text { Karyawan } \\
\text { badan } \\
\text { korporasi } \\
\text { yang } \\
\text { memerlukan } \\
\text { rekord untuk } \\
\text { melaksanaka } \\
\text { n tugas } \\
\text { mereka }\end{array}$} & \multirow[b]{2}{*}{$\begin{array}{l}\text { Tergantung } \\
\text { pada garis } \\
\text { haluan } \\
\text { (policy) } \\
\text { kearsipan } \\
\text { misalnya } \\
\text { peneliti, } \\
\text { mereka yang } \\
\text { berusia 18 } \\
\text { tahun dan } \\
\text { berdasarkan } \\
\text { syarat yang } \\
\text { ditentukan } \\
\text { oleh } \\
\text { depositor/do } \\
\text { nor arsip }\end{array}$} & \multirow[b]{2}{*}{$\begin{array}{l}\text { Perpustakaan } \\
\text { sekolah } \\
\text { hanyalah guru } \\
\text { dan murid, di } \\
\text { perpustakaan } \\
\text { umum adalah } \\
\text { setiap anggota } \\
\text { masyarakat }\end{array}$} & \\
\hline $\begin{array}{l}\text { Yang } \\
\text { disimpan }\end{array}$ & $\begin{array}{l}\text { Registrasi } \\
\text { menciptakan } \\
\text { dan } \\
\text { mengendalika } \\
\text { n rekor (aktif } \\
\text { dan inaktif) } \\
\text { yang } \\
\text { diperlukan } \\
\text { untuk } \\
\text { melaksanaka } \\
\text { n kegiatan } \\
\text { badan } \\
\text { korporasi }\end{array}$ & $\begin{array}{l}\text { Arsip yang } \\
\text { berasal dari } \\
\text { rekor inaktif } \\
\text { yang } \\
\text { diputuskan } \\
\text { untuk } \\
\text { disimpan } \\
\text { permanen. } \\
\text { Biasanya tidak } \\
\text { diterbitkan } \\
\text { unik dan } \\
\text { berbentuk } \\
\text { format } \\
\text { apapun jua }\end{array}$ & $\begin{array}{l}\text { Materi yang } \\
\text { diterbitkan } \\
\text { dalam berbagai } \\
\text { format seperti } \\
\text { kertas, film, } \\
\text { mikrofis, kaset } \\
\text { yang tidak } \\
\text { bersifat unik } \\
\text { karena } \\
\text { diterbitkan } \\
\text { dalam jumlah } \\
\text { besar }\end{array}$ & $\begin{array}{l}\text { Objek dan } \\
\text { artefak } \\
\text { (benda tiga } \\
\text { dimensi), } \\
\text { diasosiasikan } \\
\text { dengan } \\
\text { dokumentasi } \\
\text { dapat bersifat } \\
\text { unik maupun } \\
\text { tidak }\end{array}$ & & & & & \\
\hline \multirow[t]{2}{*}{$\begin{array}{l}\text { Susunan } \\
\text { material }\end{array}$} & \multirow{2}{*}{$\begin{array}{l}\text { Sistem } \\
\text { penyusunan } \\
\text { dan kontrol } \\
\text { yang dipilih } \\
\text { dikembangka } \\
\text { n dan } \\
\text { dilaksanakan } \\
\text { oleh manajer } \\
\text { rekord. } \\
\text { Pemberkasan } \\
\text { menggunaka } \\
\text { n sistem } \\
\text { terutama } \\
\text { untuk rekord } \\
\text { aktif } \\
\text { sedangkan } \\
\text { rekord inaktif } \\
\text { ditekankan } \\
\text { pada } \\
\text { pendekatan } \\
\text { administrasi }\end{array}$} & \multirow{2}{*}{$\begin{array}{l}\text { Dalam } \\
\text { susunan yang } \\
\text { ditentukan } \\
\text { dan } \\
\text { digunakan } \\
\text { oleh pencipta } \\
\text { rekord } \\
\text { (prinsip } \\
\text { original order } \\
\text { dan } \\
\text { provenanve) } \\
\text { Deskripsi } \\
\text { menggunakan } \\
\text { Internationa } \\
\text { Standard } \\
\text { Archival } \\
\text { Description } \\
\text { (ISAD) }\end{array}$} & \multirow{2}{*}{$\begin{array}{l}\text { Berdasarkan } \\
\text { sistem } \\
\text { klasifikasi dan } \\
\text { deskripsi yang } \\
\text { telah ditentukan } \\
\text { sebelumnya. } \\
\text { Untuk deskripsi } \\
\text { menggunakan } \\
\text { International } \\
\text { Standard } \\
\text { Bibliographica } \\
\text { Descrption } \\
\text { (ISBD) } \\
\text { sedangkan } \\
\text { untuk klasifikasi } \\
\text { menggunakan } \\
\text { pedoman } \\
\text { semacam } \\
\text { Dewey Decimal } \\
\text { Classification, } \\
\text { Universal } \\
\text { Decimal }\end{array}$} & \multirow[t]{2}{*}{$\begin{array}{l}\text { Penyusunan } \\
\text { materi } \\
\text { tidaklah } \\
\text { maknawi } \\
\text { (signifikan) } \\
\text { Yang utama } \\
\text { ialah kontrol } \\
\text { material }\end{array}$} & $\begin{array}{l}\text { Cara } \\
\text { menemukan } \\
\text { materi yang } \\
\text { diinginkan }\end{array}$ & $\begin{array}{l}\text { Manajer } \\
\text { rekord } \\
\text { membuat dan } \\
\text { menggunaka } \\
\mathrm{n} \text { indeks, } \\
\text { register dan } \\
\text { sebagainya } \\
\text { untuk } \\
\text { menemu } \\
\text { balik materi } \\
\text { yang tepat }\end{array}$ & $\begin{array}{l}\text { Memeriksa } \\
\text { panduan } \\
\text { inventarisasi } \\
\text { dan dokumen } \\
\text { temu balik } \\
\text { lainnya yang } \\
\text { tersedia untuk } \\
\text { pemakai }\end{array}$ & $\begin{array}{l}\text { Memeriksa } \\
\text { katalog } \\
\text { pengarang dan } \\
\text { subjel atau } \\
\text { merawak } \\
\text { langsung ke rak }\end{array}$ & $\begin{array}{l}\text { Hanya boleh } \\
\text { melihat apa } \\
\text { yang } \\
\text { dipamerkan } \\
\text { saja }\end{array}$ \\
\hline & & & & & $\begin{array}{l}\text { Cara } \\
\text { memeriksa } \\
\text { materi yang } \\
\text { diinginkan }\end{array}$ & $\begin{array}{l}\text { Berkas record } \\
\text { dapat } \\
\text { digunakan } \\
\text { setelah } \\
\text { diambail dari } \\
\text { rak } \\
\text { penyimpanan }\end{array}$ & $\begin{array}{l}\text { Di ruang baca } \\
\text { dibawah } \\
\text { pengawasan } \\
\text { arsiparisdiper } \\
\text { pustakaan } \\
\text { atau bila } \\
\text { dipinjam } \\
\text { dapat dibaca } \\
\text { di mana saja } \\
\text { sesuai dengan } \\
\text { keinginan } \\
\text { pembaca } \\
\end{array}$ & $\begin{array}{l}\text { diperpustakaan } \\
\text { atau bila } \\
\text { dipinjam dapat } \\
\text { dibaca di mana } \\
\text { saja sesuai } \\
\text { dengan } \\
\text { keinginan } \\
\text { pembaca }\end{array}$ & $\begin{array}{l}\text { Di galeri } \\
\text { pameran atau } \\
\text { ruang } \\
\text { pameran }\end{array}$ \\
\hline
\end{tabular}


KHIZANAH AL-HIKMAH Vol. 3 No. 1, Januari - Juni 2015

\begin{tabular}{|c|c|c|c|c|}
\hline $\begin{array}{l}\text { Tujuan } \\
\text { masing- } \\
\text { masing } \\
\text { lembaga }\end{array}$ & $\begin{array}{l}\text { Penyimpanan } \\
\text { kontrol dan } \\
\text { temu kembali } \\
\text { yang efisien, } \\
\text { ekonomis dan } \\
\text { sistematik } \\
\text { pada rekord } \\
\text { yang } \\
\text { diperlukan } \\
\text { untuk } \\
\text { melaksanaka } \\
n \text { tugas }\end{array}$ & $\begin{array}{l}\text { Perlindungan } \\
\text { arsip } \\
\text { termasuk } \\
\text { perlindungan } \\
\text { arsip yang } \\
\text { memiliki nilai } \\
\text { informasi, } \\
\text { historis, } \\
\text { ilmiah dan } \\
\text { pembuktian }\end{array}$ & $\begin{array}{l}\text { Mengembangka } \\
\text { koleksi yang } \\
\text { tepat dan } \\
\text { komprehensif } \\
\text { yang disimpan, } \\
\text { ditemu balik } \\
\text { dan digunakan } \\
\text { secara efektif }\end{array}$ & $\begin{array}{l}\text { Pengumpulan } \\
\text { dan } \\
\text { perlindungan } \\
\text { artefak untuk } \\
\text { masyarakat }\end{array}$ \\
\hline $\begin{array}{l}\text { Alasan } \\
\text { menunjungi } \\
\text { lembaga }\end{array}$ & $\begin{array}{l}\text { Melaksanaka } \\
\mathrm{n} \text { tugas }\end{array}$ & $\begin{array}{l}\text { Untuk bukti } \\
\text { transaksi dan } \\
\text { belajar, } \\
\text { melakukan } \\
\text { penelitian }\end{array}$ & $\begin{array}{l}\text { Untuk } \\
\text { keperluan } \\
\text { pendidikan } \\
\text { informasi, } \\
\text { penelitian dan } \\
\text { rekreasi melalui } \\
\text { bcaan }\end{array}$ & $\begin{array}{l}\text { Untuk } \\
\text { keperluar } \\
\text { pendidik } \\
\text { estetika d } \\
\text { penelitair }\end{array}$ \\
\hline $\begin{array}{l}\text { Yang } \\
\text { bertanggung } \\
\text { jawab }\end{array}$ & $\begin{array}{l}\text { Manajer } \\
\text { record }\end{array}$ & Arsiparis & pustakawan & Kurator \\
\hline $\begin{array}{l}\text { Contoh di } \\
\text { Indonesia }\end{array}$ & $\begin{array}{l}\text { Pusat rekord } \\
\text { di berbagai } \\
\text { instansi dan } \\
\text { lembaga } \\
\text { berbagai } \\
\text { commercial } \\
\text { record center }\end{array}$ & $\begin{array}{l}\text { Depo arsip } \\
\text { milik ANRI }\end{array}$ & $\begin{array}{l}\text { Perpustakaan } \\
\text { umum, khusus, } \\
\text { sekolah, } \\
\text { perguruan } \\
\text { tinggi }\end{array}$ & $\begin{array}{l}\text { Berbagi } \\
\text { museum } \\
\text { berdasarkar } \\
\text { koleksinya }\end{array}$ \\
\hline
\end{tabular}




\section{PEMBAHASAN}

Ilmu dokumentasi menurut Soejono Trimo berasal dari Ilmu Perpustakaan dan mungkin saja dapat dipandang sebagai bagian dari ilmu perpustakaan. Hal ini berdasarkan teknik-teknk yang diterapkan dalam ilmu dokumentasi sedikit banyak juga banyak mengadopsi dari Ilmu Perpustakaan walaupun pada perkembangannya terdapat penekanan-penekanan yang berbeda dari yang semula sehingga Thomas Landau mengatakan :

"documentalist differ from general librarians in that one basic qualification is specialized knowledge at graduate level of the subject in which the organize their services, and that some of the techniques they use presuppose this qualification"

Definisi di atas menunjukkan bahwa dokumentalis tetaplah beda dengan pustakawan yang berkepentingan dalam penanganan buku-buku dan lebih bersentuhan dengan penyusunan /pengolahan informasi yang terkandung dalam informasi itu sendiri atau lebih sering orang mengatakan sebagai pengemasan informasi bersama-sama dengan data-data dari sumber- sumber informasi lainnya untuk dijadikan suatu kumpulan data/informasi yang baru (Soejono Trimo,1987). Sebagai sumber dokumentasi mencakup bahan-bahan seperti:

a. Buku yang mencakup buku-buku seperti:

- Buku-buku referensi

- Buku pelajaran elementer

- Buku petunjuk atau buku pegangan atau handbook

- Buku laporan (laporan yang telah dijilid

- Buku monografi

- Disertasi

- Buku kamus

- Buku tabel-tabel

- Buku bibliografi

- Buku petunjuk telpon b. Majalah-majalah yang memuat artikelartikel hasil penelitian

c. Surat kabar

d. Manuskrip/naskah

e. Brosur, pamflet. Leaflet

f. Film

g. slide. Microfilm

h. foto, gambar, peta, grafik

i. tape/video-tape

j. katalog

k. Surat-surat dll

Koleksi-koleksi diatas adalah koleksi yang dapat diperoleh di perpustakaan dan dalam pengorganisasian dokumen di atas menggunakan pengorganisasian melalui pendekatan perpustakaan dimana pengolahan dan pengaturan dokumen diorganisir sesuai dengan pengolahan dan pengaturan agar dokumen dapat disimpan dan ditemukan kembali secara cepat. Langkah-langkah ini adalah :

- Inventarisasi

- Pengkatalogan

- Susunan dokumen

- Temu kembali dokumen

Kegiatan-kegiatan ini dapat dijabarkan sebagai berikut :

\section{1) Inventarisasi}

Kegiatan pencatatan setiap bahan pustaka yang diterima perpustakaan ke dalam buku induk atau buku inventaris meyangkut semua data bibliografi yang sesuai denga kebutuhan pelaporan dan database, sebagai bukti perbendaharaan atau kekayaan perpustakaan (Sukirno, 2012). Atau dokumen-dokumen itu sebagai bukti milik organisasi/korporasi. Dokumen-dokumen yang bersangkutan harus diinventarisasi kecuali jenis-jenis bahan pustaka yang tergolong dalam kategori ephemeral materials (seperti misalnya pamflet, brosur, leaflet dan surat-surat yang tergolong dalam kategori nonesensial) yang lazimnya tidak membutuhkan proses inventarisasi mengingat 
$\checkmark$ Data/fakta yang dikandungnya cepat kadaluwarsa sehingga harus dilakukan penyisihan secara periodik.

$\checkmark$ Secara fisik jenis bahan ini tidak dapat tahan lama sehingga tidaklah efisien bila harus diproses sebagaimana buku-buku atau dokumen lainnya (Soejono Trimo,1987 ) .

Selanjutnya proses inventarisasi ini terdiri atas beberapa pekerjaan yang meliputi pemeriksaan, pengecapan dan pendaftaran buku induk.

\section{2) Pengkatalogan}

Katalogisasi memiliki tiga fungsi umum. Pertama menunjukkan tempat suatu buku atau bahan pustaka lain menggunakan simbul-simbul angka klasifikasi dalam bentuk nomor panggil (call number) Kedua, mendaftar semua koleksi dan bahan lain dalam susunan alfabetis guna memudahkan pencarian entry-entry yang dibutuhkan. Dengan pembuatan katalog para pemakai akan lebih mudah menemukan bahan yang mereka cari dengan membaca informasi dalam katalog yang telah disusun menurut kaidah-kaidah dan sistem khusus. Katalog dibuat dengan memperhatikan ciri-ciri atau unsur-unsur khusus dari koleksi pustaka, sehingga pemakainya mudah mengenali dan menemukannya. Dengan menggunakan katalog, para pengguna dapat melihat aspek bibliografis dan kandungan setiap koleksi, menemukan lokasi rak dan mengakses informasi yang relevan (Andi Prastowo, 2012).

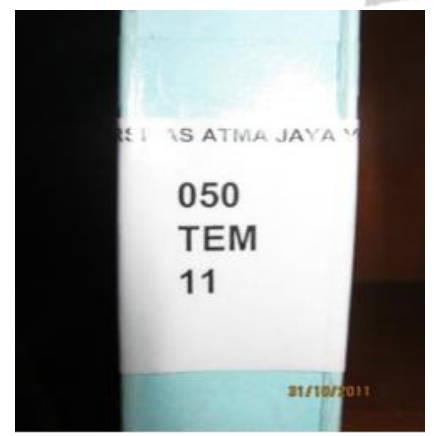

Gambar 1. Nomor panggil buku di Perpustakaan UAJY
3) Susunan Dokumen

Tujuan dari kegiatan penempatan bahan pustaka adalah:

$\checkmark$ Memudahkan pengguna dalam menemukan kembali informasi/bahan pustaka,

$\checkmark$ Memudahkan pustakawan dalam menata dan menempatkan bahan pustaka

$\checkmark$ Menciptakan keindahan/nilai estetika susunan koleksi pustaka,

$\checkmark$ sebagai sarana temu kembali.

Ada dua sistem penempatan dokumen yaitu :
a) Penempatan tetap location/order)
(fixed

Mempunyai tempat tetap.

Disusun menurut urutan penerimaan.

Ukuran atau ciri non fisik.

Susunan tidak bisa dipakai sebagai sarana temu kembali.
b) Penempatan relatif (relative location/code):

Disusun berdasarkan isinya (subjek)/nomor klas/notasi,

Dapat dipindah atau digeser,

Dokumen baru bisa disisipkan,

Bisa untuk "browsing",

Bisa dijadikan sarana temu kembali.

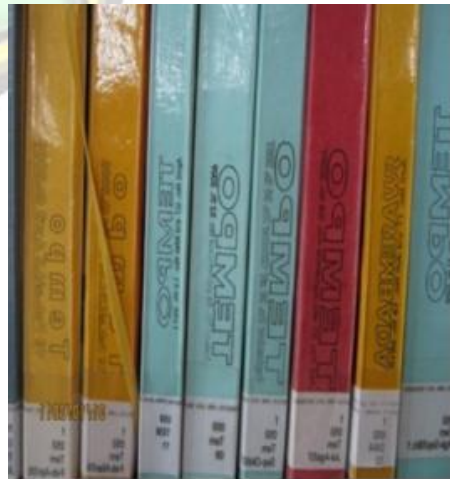

Gambar 2. Susunan penempatan relatif di Perpustakaan UAJY 
4) Temu kembali dokumen

Dalam pencarian informasi dari sekumpulan dokumen pada saat sekarang tidak lagi dilakukan secara manual. Sejak tahun 1940 telah dikembangkan sistem pencarian informasi dengan hanya mengajukan sebuah query yang merepresentasikan kebutuhan informasinya untuk selanjutnya sistem akan akan mencari sesuai dengan queri. Sistem pencarian ini disebut dengan sistem temu kembali. Sistem temu kembali informasi berasal dari kata Information Retrieval System (IRS). Temu kembali informasi adalah sebuah media layanan bagi pengguna untuk memperoleh informasi atau sumber informasi yang dibutuhkan oleh pengguna.

Sistem temu kembali informasi merupakan sistem informasi yang berfungsi untuk menemukan informasi yang relevan dengan kebutuhan pemakai. Sistem temu kembali informasi berfungsi sebagai perantara kebutuhan informasi pengguna dengan sumber informasi yang tersedia. Pengertian yang sama mengenai sistem temu kembali informasi menurut Sulistyo-Basuki, sistem temu kembali informasi adalah kegiatan yang bertujuan untuk menyediakan dan memasok informasi bagi pemakai sebagai jawaban atas permintaan atau berdasarkan kebutuhan pemakai. Dapat dinyatakan bahwa sistem temu kembali informasi memiliki fungsi dalam menyediakan kebutuhan informasi sesuai dengan kebutuhan dan permintaan penggunanya.

Definisi lain yang mengemukakan bahwa: "Sistem temu kembali informasi adalah suatu proses yang dilakukan untuk menemukan dokumen yang dapat memberikan kepuasan bagi pengguna dalam memenuhi kebutuhan informasinya'. Tujuan utama sistem temu kembali informasi adalah untuk menemukan dokumen yang sesuai dengan kebutuhan informasi pengguna secara efektif dan efisien, sehingga dapat memberikan kepuasan baginya, dan sasaran akhir dari sistem temu kembali informasi adalah kepuasan pemakai.
Sistem temu kembali informasi merupakan ilmu pengetahan yang berfungsi dalam penempatan sejumlah dokumen dalam memenuhi kebutuhan informasi pengguna. Menurut Hasugian, dasar dari sistem temu balik informasi adalah proses untuk mengidentifikasi kecocokan diantara permintaan dengan representasi atau indeks dokumen, kemudian mengambil dokumen dari suatu simpanan sebagai jawaban atas pemintaan tersebut. Sistem temu kembali informasi pada prinsipnya bekerja berdasarkan ukuran antara istilah query dengan istilah yang menjadi representasi dokumen. Pengertian lain yang menyatakan bahwa Sistem temu kembali informasi adalah proses yang berhubungan dengan representasi, penyimpanan, pencarian, dan pemanggilan informasi yang relavan dengan kebutuhan informasi yang diinginkan pengguna. Pendapat ini menunjukkan bahwa dalam Sistem Temu Kembali Informasi terkandung sejumlah kegiatan yang meliputi proses identifikasi kecocokan, representasi, penyimpanan, pengambilan, serta pencarian atau penelusuran dokumen yang relevan atau sesuai, dalam rangka memenuhi kebutuhan informasi pengguna. Maka dapat disimpulkan bahwa sistem temu kembali informasi merupakan sebuah sistem yang berguna dalam memanggil dan menempatkan dokumen dari/dalam basis data sesuai dengan permintaan pengguna.

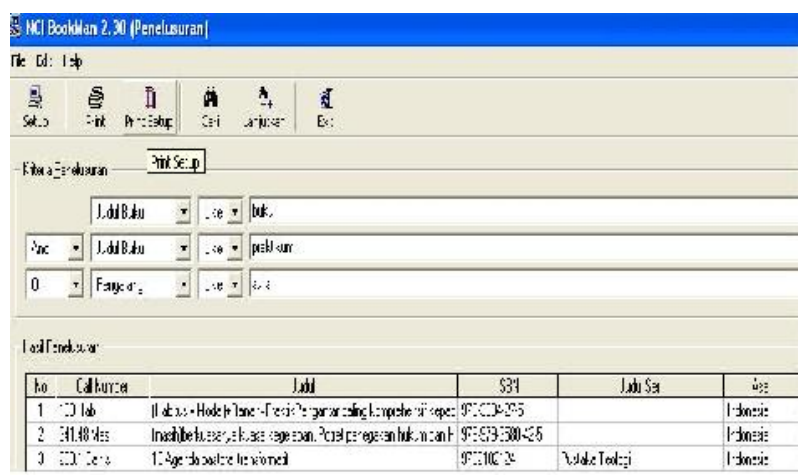

Gambar 3. Contoh sebuah aplikasi sistem temu balik informasi 


\section{KESIMPULAN DAN SARAN}

\section{a. Kesimpulan}

Salah satu fungsi dokumen adalah sebagai sarana pengingat yang disimpan dalam berbagai bentuk maka diperlukan sistem temu kembali yang efisien dan efektif. Fungsi manajemen arsip yang baik diperlukan sehingga proses pekerjaan dapat berlangsung dengan baik. Manajemen sebagai proses untuk mencapai tujuan organisasi memerlukan dokumentasi yang dapat memberikan bantuannya bila diperlukan. Efisien di sini maksudnya adalah suatu keadaan ketika penyelesaian suatu pekerjaan dilaksanakan secara tepat dan akurat tanpa membuang waktu, tenaga dan biaya. Adapun efektif maksudnya adalah suatu keadaan dalam memilih cara dan peralatan yang digunakan dengan tepat sehingga tujuan yang diinginkan dapat dicapai dengan hasil yang memuasakan.

\section{b. Saran}

Setelah melihat uraian di atas maka dokumentasi seharusnya pada setiap lembaga mendapatkan perhatian sendiri karena dari pengorganisasian dokumen yang baik dapat meningkatkan nilai tambah suatu organisasi atau perusahaan seperti meningkatkan strategi perusahaan dalam pencapaian profit yang baik sehingga dapat memberikan image yang baik dalam sebuah perusahaan. Dengan pengorganisasian yang baik pula hubungan yang baik dengan pelanggan atau customer dapat lebih ditingkatkan sehingga dapat memberikan peluang baru dalam membuka peluang baru .

\section{DAFTAR PUSTAKA}

Nunuk Nuryani, A. "Upaya Pemerintah Meningkatkan Peran Masyarakat Dalam Pengembangan Kearsipan" dalam Khazanah Buletin Kearsipan UGM Vol 4 Nomor 3.
Prastowo, A. (2012). Manajemen Perpustakaan Sekolah Profesional, Yogyakarta : Diva press.

Purwono, Dokumentasi. Yogyakarta : Graha Ilmu , 2010.

Sukirno, Bahan kuliah Manajemen Rekaman dan Dokumen di Program Pascasarjana Konsentrasi Ilmu Perpustakaan dan Informasi UIN Sunan Kalijaga, 2011.

Sulistyo-Basuki. Bahan kuliah Perpustakaan dan Informasi dalam Konteks Sosial Budaya yang UIN Suka Yogyakarta, 2011,

Sulistyo-Basuki dalam Opong Sumiati \& Nurahman Arief , Pengantar Ilmu Perpustakaan Bahan Ajar Diklat Calon Pustakawan Tingkat Ahli, Perpustakaan Nasional RI , 2004

Trimo, S. Pengantar Ilmu Dokumentasi. Bandung : Remadja Karya, 1987.

Wursanto, Kearsipan 2 , Yogyakarta: Kanisius, 1991. 